\title{
Relationships between the physical properties and biodegradability and bacteria toxicity of fatty acid-based ionic liquids
}

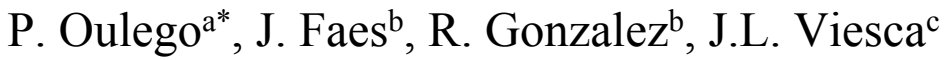 \\ D. Blanco ${ }^{\mathrm{c}}, \mathrm{A}$. Hernández Battez $\mathrm{c}^{\mathrm{c}, \mathrm{d}}$ \\ ${ }^{a}$ Department of Chemical and Environmental Engineering, University of Oviedo, Asturias, Spain \\ ${ }^{\mathrm{b}}$ Department of Marine Science and Technology, University of Oviedo, Asturias, Spain \\ 'Department of Construction and Manufacturing Engineering, University of Oviedo, Asturias, Spain \\ ${ }^{d}$ Department of Design and Engineering, Bournemouth University, Poole, BH12 5BB, UK \\ (*)Email: oulegopaula@uniovi.es
}

\begin{abstract}
This work is focused on the correlation between several physical properties (kinematic viscosity, viscosity index, refractive index, density and water solubility) and biodegradability and bacteria toxicity of a family of ionic liquids synthesized from fatty acids as anion precursor (FAILs): methyltrioctylammonium hexanoate $\left[\mathrm{N}_{8881}\right]\left[\mathrm{C}_{6: 0}\right]$, methyltrioctylammonium octanoate $\left[\mathrm{N}_{8881}\right]\left[\mathrm{C}_{8: 0}\right]$, methyltrioctylammonium laurate $\left[\mathrm{N}_{8881}\right]\left[\mathrm{C}_{12: 0}\right]$, methyltrioctylammonium palmitate $\left[\mathrm{N}_{8881}\right]\left[\mathrm{C}_{16: 0}\right]$, methyltrioctylammonium stearate $\left[\mathrm{N}_{8881}\right]\left[\mathrm{C}_{18: 0}\right]$ and methyltrioctylammonium oleate $\left[\mathrm{N}_{8881}\right]\left[\mathrm{C}_{18: 1}\right]$. To that end, new values of these physical properties, biodegradability and bacteria toxicity were determined, although literature data for the $\left[\mathrm{N}_{8881}\right]\left[\mathrm{C}_{8: 0}\right],\left[\mathrm{N}_{8881}\right]\left[\mathrm{C}_{12: 0}\right]$ and $\left[\mathrm{N}_{8881}\right]\left[\mathrm{C}_{16: 0}\right]$ FAILs were also needed. It was found a good linear relationship $\left(\mathrm{r}^{2}>0.90\right)$ between the biodegradability index $\left(\mathrm{BOD}_{5} / \mathrm{COD}\right)$ and the logarithm of kinematic viscosity, refractive index and water solubility for the saturated FAILs. Besides, the toxicity on both Vibrio fischeri and Escherichia Coli can be successfully predicted using the logarithm of kinematic viscosity and viscosity index. Therefore, kinematic viscosity, which is an essential parameter for a lubricant, is the most promising physical property to estimate both biodegradability and bacteria toxicity of a family of ionic liquids. The double bond in the structure of the unsaturated FAIL $\left(\left[\mathrm{N}_{8881}\right]\left[\mathrm{C}_{18: 1}\right]\right)$ is responsible for the worsening of the linear dependence between physical and environmental properties.
\end{abstract}

Keywords: bacteria toxicity; biodegradability; fatty acids; ionic liquids; lubrication; physical properties

\section{Introduction}

Room temperature ionic liquids (ILs) are salts mainly composed of ions, which show melting points below $100^{\circ} \mathrm{C}$. Generally, the cationic part consists of organic substances, whereas the anionic one is made up of organic or inorganic compounds [1-3]. These materials exhibit negligible vapour pressure, nonflammability, good conductivity, inherent polarity and excellent oxidative and thermal stability [4]. For this reason, their use is gaining increasing attention in several applications, such as organic synthesis, catalysis, surface science and electrochemistry, among others [5-8]. These properties also make ILs highly attractive for potential applications in the lubrication field. In this sense, ILs can be used as neat lubricant or lubricant additive in order to decrease friction and wear in various tribological pairs, such as steel-steel, copper-steel, aluminum-steel and steel-composite, among others [1,9-16). This is due to the fact that ILs can form tribofilms on the surface of these materials improving their tribological behaviour [17-19]. Nevertheless, the ILs commonly used in lubrication present in their composition halogen anions $\left(\left[\mathrm{PF}_{6}\right]^{-},\left[\mathrm{BF}_{4}\right]^{-}, \mathrm{NTf}_{2}\right]^{-}$ and [FAP]-, among others), aromatic cations (imidazolium) and metals (zinc), which can cause negative 
effects in the environment. It should be noted that some ILs are soluble in water, which can cause surface water and groundwater pollution [20]. Taking into account that an important amount of lubricants can come in contact with the environment, especially in watercourses and soils, due to accidental spill or effluent discharges, and the continuous toughening of the EU regulation, it is increasing necessary to develop sustainable ILs [21]. For these reasons, new ionic liquids are being synthesized using various renewable sources including proteins, polysaccharides (cellulose, chitin), lignin, fatty acids and cholinium [22-25]. In order to evaluate the environmental friendliness of the ILs, toxicity assays using different types of (micro)organisms, such as bacteria, fungi, algae, cladoceran and fish, among others were performed [26]. Besides, biodegradability tests were also carried out, since biodegradation is the main route employed by microorganisms to degrade this type of substances from water compartments and soil [27]. The environmental hazard assessment is highly dependent on the species used in the study and requires a great deal of effort to gain an in-depth knowledge. Moreover, physical properties, such as density and viscosity are crucial in the lubrication field to define the thermal operating window. This makes essential the correlation of the physical and environmental properties of the ILs. As far as we know, few works studied the correlation of these characteristics, and the existing ones only considered their influence on biodegradability [28-30]. Because of the measurement of the environmental properties can be a complex task, correlating them with physicochemical properties of easy determination can be interesting from the point of view of lubrication. Therefore, the aim of this work is to correlate several physical properties, such as kinematic viscosity, viscosity index, refractive index, density and water solubility with biodegradability and bacteria toxicity of fatty-acid based ionic liquids. For this purpose, kinematic viscosity, water solubility and refractive index were measured for the $\left[\mathrm{N}_{8881}\right]\left[\mathrm{C}_{6: 0}\right],\left[\mathrm{N}_{8881}\right]\left[\mathrm{C}_{8: 0}\right],\left[\mathrm{N}_{8881}\right]\left[\mathrm{C}_{12: 0}\right],\left[\mathrm{N}_{8881}\right]\left[\mathrm{C}_{16: 0}\right]$, $\left[\mathrm{N}_{8881}\right]\left[\mathrm{C}_{18: 0}\right]$ and $\left[\mathrm{N}_{8881}\right]\left[\mathrm{C}_{18: 1}\right]$ FAILs at $30^{\circ} \mathrm{C}$. Besides, density was also measured for the $\left[\mathrm{N}_{8881}\right]\left[\mathrm{C}_{6: 0}\right]$, $\left[\mathrm{N}_{8881}\right]\left[\mathrm{C}_{18: 0}\right]$ and $\left[\mathrm{N}_{8881}\right]\left[\mathrm{C}_{18: 1}\right]$ FAILs at $30^{\circ} \mathrm{C}$ and kinematic viscosity at $40^{\circ} \mathrm{C}$ and $100^{\circ} \mathrm{C}$ in order to calculate viscosity index for the same FAILs. Regarding biodegradability, this parameter was determined for the $\left[\mathrm{N}_{8881}\right]\left[\mathrm{C}_{6: 0}\right],\left[\mathrm{N}_{8881}\right]\left[\mathrm{C}_{18: 0}\right]$ and $\left[\mathrm{N}_{8881}\right]\left[\mathrm{C}_{18: 1}\right]$ FAILs. Considering bacteria toxicity, the values of $\mathrm{EC}_{50}$ and $\mathrm{TU}$ for Escherichia coli were measured for all of the FAILs here studied: $\left[\mathrm{N}_{8881}\right]\left[\mathrm{C}_{6: 0}\right]$, $\left[\mathrm{N}_{8881}\right]\left[\mathrm{C}_{8: 0}\right],\left[\mathrm{N}_{8881}\right]\left[\mathrm{C}_{12: 0}\right],\left[\mathrm{N}_{8881}\right]\left[\mathrm{C}_{16: 0}\right],\left[\mathrm{N}_{8881}\right]\left[\mathrm{C}_{18: 0}\right]$ and $\left[\mathrm{N}_{8881}\right]\left[\mathrm{C}_{18: 1}\right]$, while the $\mathrm{EC}_{50}$ and TU for Vibrio fischeri were only determined for the $\left[\mathrm{N}_{8881}\right]\left[\mathrm{C}_{6: 0}\right],\left[\mathrm{N}_{8881}\right]\left[\mathrm{C}_{18: 0}\right]$ and $\left[\mathrm{N}_{8881}\right]\left[\mathrm{C}_{18: 1}\right]$ FAILs. 


\section{Materials and Methods}

\subsection{Fatty acid-based ionic liquids}

The fatty acid-based ionic liquids (FAILs) were synthesized by means of a salt metathesis reaction according to Battez et al. [31]. The details related to their identification through ${ }^{1} \mathrm{H}$ and ${ }^{13} \mathrm{C}$ NMR and FTIR analyses can also be found in Battez et al. [31] and Blanco et al. [32]. Methyltrioctylammonium bromide ionic liquid ( $\geq 97 \%$ ) was employed as cation precursor and natural fatty acids: hexanoic $(\geq 98 \%)$, octanoic $(\geq 98 \%)$, lauric $(\geq 98 \%)$, palmitic $(\geq 98 \%)$, stearic $(\geq 98 \%)$ and oleic $(\geq 95 \%)$ acids were used as anion precursors. Fig. 1 shows their chemical structure and abbreviation. Each of the precursors were supplied by Sigma-Aldrich and employed without any further purification.

Methyltrioctylammonium hexanoate, $\left[\mathrm{N}_{8881}\right]\left[\mathrm{C}_{6: 0}\right]$

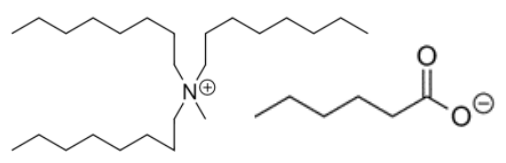

Methyltrioctylammonium laurate, $\left[\mathrm{N}_{8881}\right]\left[\mathrm{C}_{12: 0}\right]$

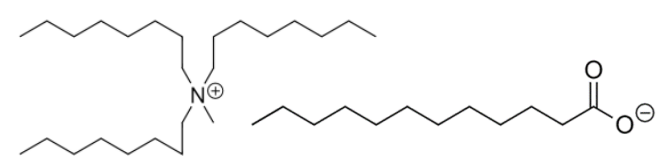

Methyltrioctylammonium stearate, $\left[\mathrm{N}_{8881}\right]\left[\mathrm{C}_{18: 0}\right]$

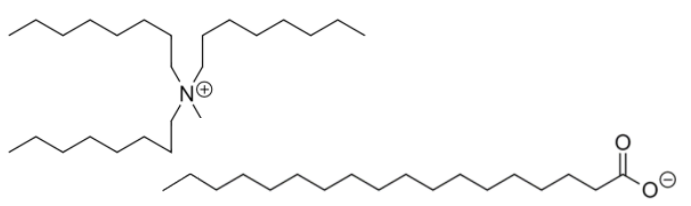

Methyltrioctylammonium octanoate, $\left[\mathrm{N}_{8881}\right]\left[\mathrm{C}_{8: 0}\right]$

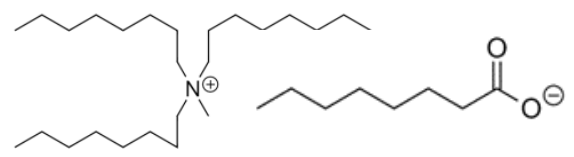

Methyltrioctylammonium palmitate, $\left[\mathrm{N}_{8881}\right]\left[\mathrm{C}_{16: 0}\right]$

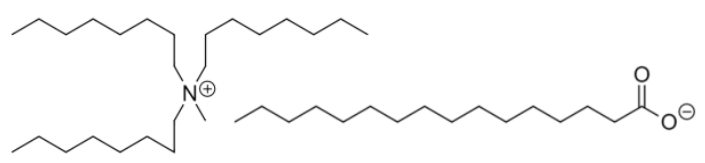

Methyltrioctylammonium oleate, $\left[\mathrm{N}_{8881}\right]\left[\mathrm{C}_{18: 1}\right]$

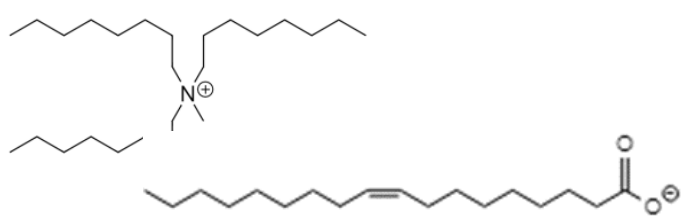

Fig. 1 Chemical structures and abbreviations of the FAILs analysed.

\subsection{Determination of physical properties}

Density and dynamic viscosity of the fatty acid-based ionic liquids were determined according to ASTM D7042 from 30 to $100{ }^{\circ} \mathrm{C}$ at atmospheric pressure using a Stabinger Viscometer SVM3001. From these data, the equipment directly calculates the kinematic viscosity and the viscosity index according to the ASTM D2270-04.

Refractive index was determined at $30^{\circ} \mathrm{C}$ by the critical angle method using a monochromatic source (sodium lamp) with an Abbe refractometer WYA-15. 
Water solubility data were obtained mixing $2 \mathrm{~g}$ of each of the FAILs with $4 \mathrm{~g}$ of distilled water and the resulting mixtures were then stirred for $2 \mathrm{~min}$ in a vortex mixer and centrifuged (10000 rpm, $10 \mathrm{~min})$. The main phase (FAIL-poor phase) corresponds to the aqueous one. Since the FAILs are less dense than water, the FAIL-poor aqueous phases were below the FAIL-rich phases. The concentration of the FAILs in the aqueous phase was determined by measuring total organic carbon (TOC) with a Shimadzu TOC-V $\mathrm{V}_{\mathrm{CSH}}$ analyser. The following equation (eq. 1) was used to calculate the FAIL concentrations [33]:

$\operatorname{conc}_{F A I L}(g / L)=\operatorname{conc}_{T O C}(g C / L) \times \frac{1 m o l-g C}{12.011 g C} \times \frac{1 m o l-g F A I L}{n m o l-g C} \times \frac{I L_{M W}}{1 m o l-g \text { FAIL }}$

where: conc $_{\mathrm{FAIL}}$ is the FAIL concentration, conc $_{\mathrm{TOC}}$ is the TOC concentration, $\mathrm{n}$ is the number of carbon atoms of the FAIL and $\mathrm{IL}_{\mathrm{MW}}$ is the molecular weight of the IL.

\subsection{Environmental properties of FAILs}

\subsubsection{Preparation of the aqueous solutions of the FAILs}

The aqueous solutions were prepared following the procedure indicated for the determination of water solubility. These solutions were employed to prepare the stock ones used in the determination of toxicity and biodegradability. The FAIL concentrations were determined in the same manner as with water solubility.

\subsubsection{Biodegradability: chemical and biochemical oxygen demand}

The biochemical oxygen demand $\left(\mathrm{BOD}_{5}\right)$ were measured by means of a Lovibond BOD respirometric system. Aqueous solutions of $0.1 \mathrm{~g} / \mathrm{L}$ were prepared for each of the FAILs and the $\mathrm{pH}$ was adjusted to 7.0 \pm 0.2 with $0.5 \mathrm{M} \mathrm{NaOH}$ using a Crison Basic $20 \mathrm{pH}$-meter. A solution of $0.1 \mathrm{~g} / \mathrm{L}$ of sodium acetate was employed as a control sample. It was necessary to inoculate each FAIL solution $(94 \mathrm{~mL})$ with an aerobic bioreactor effluent $(1 \mathrm{~mL})$. Then, the samples were incubated for 5 days in dark conditions at $20{ }^{\circ} \mathrm{C}$. Chemical oxygen demand (COD) concentrations were measured using the dichromate method at $600 \mathrm{~nm}$ with a Hach DR/2500 spectrophotometer. All analyses were carried out in triplicate.

\subsubsection{Bacterial Toxicity: Vibrio fischeri tests}

The assessment of the bacterial toxicity was performed using a commercial test, Biofix ${ }^{\circledR}$ Lumi-10, which employs a lyophilized strain of Vibrio fischeri (NRRL B-11177), in accordance with the standard protocol of ISO 11348-3 [33]. To that end, $0.5 \mathrm{~g} / \mathrm{L}$ of FAIL solutions were diluted in serial dilutions between $1: 2$ and 1:1024. It was needed to adjust the salinity of the samples to $2 \%$ and the $\mathrm{pH}$ to neutrality. Besides, it was also necessary to keep the temperature at $15{ }^{\circ} \mathrm{C}$ using a water bath. Toxicity data were expressed in 
line with that of the ISO 11348-3 [34]. The inhibition percentage was determined by comparison of the drop in light emission with a control sample $(2 \% \mathrm{NaCl}$ solution) after 15 min of contact with the bacteria. Considering that bacterial luminescence, that is to say, light emission, is directly linked to cellular respiration, a fall in light emission is provoked by a reduction in their respiration due to the toxicity of these substances to the bacteria. In this sense, $\mathrm{EC}_{50}$, i.e., the $\mathrm{FAIL}$ concentration that reduces $50 \%$ the luminescence of bacteria after 15 min of contact time, was determined [27]. Furthermore, the toxic units (TU) were calculated after 15 min of exposure. This unitless parameter is obtained dividing the FAIL concentration $(100 \%)$, by lethal end-point $\left(\mathrm{EC}_{50}\right)$, as indicated in the equation 2 [35]. This parameter makes easier the understanding of toxicity assessment because a rise in the TU value is associated with a rise in the toxicity.

$$
T U=\frac{1}{E C_{50}} \times 100
$$

Based on TU values, the compounds can be classified into four categories: i) non-toxic: TU values $<1$, ii) toxic: TU values from 1 to 10 , iii) very toxic: TU values between 10 and 100, and iv) extremely toxic: TU values $>100[27 ; 36]$. All analytical measurements were performed in triplicate.

\subsubsection{Bacterial Toxicity: Escherichia coli tests}

A commercial assay, Toxi-ChromoTest (epbi - version 3.6), was used to complete the bacterial toxicity assessment of the FAILs. This is a colorimetric test based on the capacity of the various compounds to inhibit the $\beta$-galactosidase enzyme in a highly sensitive Escherichia coli strain. These tests were also performed with FAIL solutions of $0.5 \mathrm{~g} / \mathrm{L}$ diluted serially in 2-fold steps from 1:2 to 1:1024. The contact time of the bacteria to the FAIL samples was 90 min. After this incubation period, blue chromogen (chromogenic substance) was added. It should be noted that blue colour rapidly appears in non-toxic substances, whereas no colour is observed in the toxic ones. This colour was quantified measuring the optical density with a Cary Uv/Vis spectrophotometer at $615 \mathrm{~nm}$. The toxicity (degree of inhibition) was calculated by comparison with the optical density of a toxic-free control sample. A solution of $4 \mathrm{~g} / \mathrm{L}$ of mercury chloride was employed as a standard toxic substance in order to verify the viability of the $E$. coli strain. Both the values of $\mathrm{EC}_{50}$, that is to say the concentration that inhibits enzymatic activity by $50 \%$, and TU units were calculated after 90 min of incubation. 


\section{Results and discussion}

\subsection{Correlation between physical and environmental properties}

Tables 1 and 2 show the main physical properties, the biodegradability indices $\left(\mathrm{BOD}_{5} / \mathrm{COD}\right)$ and the values of $\mathrm{EC}_{50}$ and TU for Vibrio fischeri (V. fischeri) and Escherichia coli (E. coli) of the fatty-acid based ionic liquids here studied. It should be noted that these tables contained both new experimental data and literature values for the $\left[\mathrm{N}_{8881}\right]\left[\mathrm{C}_{6: 0}\right],\left[\mathrm{N}_{8881}\right]\left[\mathrm{C}_{12: 0}\right]$ and $\left[\mathrm{N}_{8881}\right]\left[\mathrm{C}_{16: 0}\right]$ FAILs from a previous work [31]. In this sense, the new experimental values determined were: i) water solubility, kinematic viscosity and refractory index for the $\left[\mathrm{N}_{8881}\right]\left[\mathrm{C}_{6: 0}\right],\left[\mathrm{N}_{8881}\right]\left[\mathrm{C}_{8: 0}\right],\left[\mathrm{N}_{8881}\right]\left[\mathrm{C}_{12: 0}\right],\left[\mathrm{N}_{8881}\right]\left[\mathrm{C}_{16: 0}\right],\left[\mathrm{N}_{8881}\right]\left[\mathrm{C}_{18: 0}\right]$ and $\left[\mathrm{N}_{8881}\right]\left[\mathrm{C}_{18: 1}\right]$ FAILs at $30^{\circ} \mathrm{C}$, ii) density for the $\left[\mathrm{N}_{8881}\right]\left[\mathrm{C}_{6: 0}\right],\left[\mathrm{N}_{8881}\right]\left[\mathrm{C}_{18: 0}\right]$ and $\left[\mathrm{N}_{8881}\right]\left[\mathrm{C}_{18: 1}\right] \mathrm{FAILs}$ at $30^{\circ} \mathrm{C}$, iii) kinematic viscosity at $40^{\circ} \mathrm{C}$ and $100^{\circ} \mathrm{C}$ in order to calculate viscosity index for the same FAILs like in the case of density measurement, iv) biodegradability for the $\left[\mathrm{N}_{8881}\right]\left[\mathrm{C}_{6: 0}\right],\left[\mathrm{N}_{8881}\right]\left[\mathrm{C}_{18: 0}\right]$ and $\left[\mathrm{N}_{8881}\right]\left[\mathrm{C}_{18: 1}\right]$ FAILs, v) E. coli toxicity $\left(\mathrm{EC}_{50}\right.$ and TU values) for the $\left[\mathrm{N}_{8881}\right]\left[\mathrm{C}_{6: 0}\right],\left[\mathrm{N}_{8881}\right]\left[\mathrm{C}_{8: 0}\right],\left[\mathrm{N}_{8881}\right]\left[\mathrm{C}_{12: 0}\right],\left[\mathrm{N}_{8881}\right]\left[\mathrm{C}_{16: 0}\right],\left[\mathrm{N}_{8881}\right]\left[\mathrm{C}_{18: 0}\right]$ and $\left[\mathrm{N}_{8881}\right]\left[\mathrm{C}_{18: 1}\right]$ FAILs and vi) $V$. fischeri toxicity ( $\mathrm{EC}_{50}$ and TU values) for the $\left[\mathrm{N}_{8881}\right]\left[\mathrm{C}_{6: 0}\right],\left[\mathrm{N}_{8881}\right]\left[\mathrm{C}_{18: 0}\right]$ and $\left[\mathrm{N}_{8881}\right]\left[\mathrm{C}_{18: 1}\right]$. Only in the case of $\left[\mathrm{N}_{8881}\right]\left[\mathrm{C}_{6: 0}\right] \mathrm{IL}$, the value of $\mathrm{BOD}_{5} / \mathrm{COD}$ was higher than 0.2 , thus indicating that this IL is readily biodegradable [37]. In terms of toxicity, all of the FAILs can be considered toxic compounds since $\mathrm{EC}_{50}$ values fell within the range from 10 to $100 \mathrm{mg} / \mathrm{L}$ and $\mathrm{TU}$ showed values between 1 and 10 . 
Table 1 Physical properties of the FAILs studied.

\begin{tabular}{|c|c|c|c|c|c|c|c|}
\hline \multirow{2}{*}{$\begin{array}{c}\text { Ionic } \\
\text { liquids }\end{array}$} & \multirow{2}{*}{$\begin{array}{l}\text { Solubility at } 30^{\circ} \mathrm{C} \\
\left(\mathrm{g}_{\text {FAIL }} / \mathbf{m L} \text { of } \mathrm{H}_{2} \mathrm{O}\right)\end{array}$} & \multirow{2}{*}{$\begin{array}{c}\text { Density at } \\
30^{\circ} \mathrm{C}\left(\mathrm{g} / \mathrm{cm}^{3}\right)\end{array}$} & \multicolumn{3}{|c|}{ Kinematic viscosity $\left(\mathrm{mm}^{2} / \mathbf{s}\right)$} & \multirow{2}{*}{$\begin{array}{c}\text { Viscosity index } \\
\text { ASTM D2270 }\end{array}$} & \multirow{2}{*}{$\begin{array}{c}\text { Refractive } \\
\text { index at } 30^{\circ} \mathrm{C}\end{array}$} \\
\hline & & & $30^{\circ} \mathrm{C}$ & $40^{\circ} \mathrm{C}$ & $100^{\circ} \mathrm{C}$ & & \\
\hline$\left[\mathrm{N}_{8881}\right]\left[\mathrm{C}_{6: 0}\right]$ & $2.80 \cdot 10^{-3} \pm 8.5 \cdot 10^{-3}$ & 0.9233 & 2752.9 & 1284.9 & 56.5 & 92 & $1.4750 \pm 0.0001$ \\
\hline$\left[\mathrm{N}_{8881}\right]\left[\mathrm{C}_{8: 0}\right]^{*}$ & $2.37 \cdot 10^{-3} \pm 8.9 \cdot 10^{-3}$ & 0.8934 & 2410.3 & 1121.2 & 48.6 & 85 & $1.4660 \pm 0.0002$ \\
\hline$\left[\mathrm{N}_{8881}\right]\left[\mathrm{C}_{12: 0}\right]^{*}$ & $1.53 \cdot 10^{-3} \pm 9.1 \cdot 10^{-3}$ & 0.8768 & 1475.8 & 715.7 & 36.9 & 85 & $1.4654 \pm 0.0001$ \\
\hline$\left[\mathrm{N}_{8881}\right]\left[\mathrm{C}_{16: 0}\right]^{*}$ & $1.40 \cdot 10^{-3} \pm 3.4 \cdot 10^{-3}$ & 0.8784 & 1188.3 & 596.3 & 37.4 & 99 & $1.4647 \pm 0.0003$ \\
\hline$\left[\mathrm{N}_{8881}\right]\left[\mathrm{C}_{18: 0}\right]$ & $1.34 \cdot 10^{-3} \pm 2.3 \cdot 10^{-3}$ & 0.8778 & 1033.2 & 524.2 & 35.1 & 102 & $1.4620 \pm 0.0001$ \\
\hline$\left[\mathrm{N}_{8881}\right]\left[\mathrm{C}_{18: 1}\right]$ & $1.30 \cdot 10^{-3} \pm 6 \cdot 10^{-3}$ & 0.9155 & 1234.7 & 627.2 & 39.3 & 101 & $1.4683 \pm 0.0007$ \\
\hline
\end{tabular}

*Values of density, kinematic viscosity $\left(40^{\circ} \mathrm{C}\right.$ and $\left.100^{\circ} \mathrm{C}\right)$ and viscosity index obtained from a previous work [31].

Table 2 Environmental properties of the FAILs studied.

\begin{tabular}{|c|c|c|c|c|c|c|c|}
\hline Ionic liquids & $\begin{array}{c}\text { V. fischeri } \\
\mathbf{E C}_{50} \\
(\mathrm{mg} / \mathrm{L})^{\mathrm{a}}\end{array}$ & $\begin{array}{c}V \cdot \text { fischeri } \\
\text { TU }^{\mathrm{b}}\end{array}$ & $\begin{array}{c}E . \text { coli } \\
\mathrm{EC}_{50} \\
(\mathrm{mg} / \mathbf{L})^{\mathrm{a}}\end{array}$ & $\begin{array}{c}\text { E. Coli } \\
\text { TU }^{\mathbf{b}}\end{array}$ & $\begin{array}{c}\mathrm{COD} \\
\left(\mathrm{mg} \mathrm{O} \mathrm{O}_{2} / \mathrm{L}\right)\end{array}$ & $\begin{array}{c}\mathrm{BOD}_{5} \\
\left(\mathrm{mg} \mathrm{O}_{2} / \mathrm{L}\right)\end{array}$ & $\mathrm{BOD}_{5} / \mathrm{COD}$ \\
\hline$\left[\mathrm{N}_{8881}\right]\left[\mathrm{C}_{6: 0}\right]$ & $66.8 \pm 0.5$ & $1.50 \pm 0.01$ & $61.3 \pm 0.9$ & $1.63 \pm 0.02$ & $416 \pm 3$ & $89.0 \pm 1$ & $0.22 \pm 0.02$ \\
\hline$\left[\mathrm{N}_{8881}\right]\left[\mathrm{C}_{8: 0}\right]^{*}$ & $59.3 \pm 0.7$ & $1.69 \pm 0.02$ & $55.1 \pm 0.8$ & $1.81 \pm 0.03$ & $424 \pm 1$ & $83.5 \pm 0.7$ & $0.20 \pm 0.01$ \\
\hline$\left[\mathrm{N}_{8881}\right]\left[\mathrm{C}_{12: 0}\right]^{*}$ & $53.9 \pm 0.1$ & $1.86 \pm 0.01$ & $49.9 \pm 0.1$ & $2.00 \pm 0.01$ & $430 \pm 2$ & $75.0 \pm 1$ & $0.17 \pm 0.02$ \\
\hline$\left[\mathrm{N}_{8881}\right]\left[\mathrm{C}_{16: 0}\right]^{*}$ & $45.4 \pm 0.4$ & $2.20 \pm 0.02$ & $38.1 \pm 0.2$ & $2.63 \pm 0.02$ & $427 \pm 2$ & $69.5 \pm 2$ & $0.16 \pm 0.03$ \\
\hline$\left[\mathrm{N}_{8881}\right]\left[\mathrm{C}_{18: 0}\right]$ & $41.6 \pm 0.3$ & $2.40 \pm 0.03$ & $38.1 \pm 0.2$ & $2.63 \pm 0.02$ & $424 \pm 2$ & $62.0 \pm 1$ & $0.15 \pm 0.02$ \\
\hline$\left[\mathrm{N}_{8881}\right]\left[\mathrm{C}_{18: 1}\right]$ & $11.6 \pm 0.5$ & $8.7 \pm 0.4$ & $10.4 \pm 0.5$ & $9.6 \pm 0.5$ & $431 \pm 5$ & $56.5 \pm 0.7$ & $0.13 \pm 0.02$ \\
\hline
\end{tabular}

*Values of V. fischeri $\mathrm{EC}_{50}$, V. fischeri TU, $\mathrm{COD}, \mathrm{BOD}$ and $\mathrm{BOD}_{5} / \mathrm{COD}$ obtained from a previous work [31].

${ }^{a} \mathbf{E C}_{50}$ classification for aquatic life: non-toxic: $\mathrm{EC}_{50}>100 \mathrm{mg} / \mathrm{L}$; harmful (acute 3): $\mathrm{EC}_{50}: 10-100 \mathrm{mg} / \mathrm{L}$; toxic (acute 2):

$\mathrm{EC}_{50}: 1-10 \mathrm{mg} / \mathrm{L}$; and very toxic (acute 1$): \mathrm{EC}_{50}<1 \mathrm{mg} / \mathrm{L}$.

b TU classification: non-toxic: TU $<1$; toxic: TU: $1-10$; very toxic: TU: $10-100$ and extremely toxic: $\mathrm{TU}>100$ 


\subsubsection{Kinematic viscosity}

The FAILs here studied exhibited a wide range of kinematic viscosity values, ranging from around 627 to $1285 \mathrm{~mm}^{2} \cdot \mathrm{s}^{-1}$ at $40{ }^{\circ} \mathrm{C}$. In this case, the biodegradability index of the FAILs increased with a rise in kinematic viscosity values, whereas the value of TU for both $V$. fischeri and E. coli slightly decreased. These results are interesting since viscosity is a lubricant fundamental parameter for the film formation properties. Besides, the relationships between biodegradability index and TU for both $V$. fischeri and $E$. coli and the logarithm of kinematic viscosity have been found to be linear. The value of $\mathrm{r}^{2}$ was $0.92,0.93$ and 0.91 , for biodegradability index, TU for $V$. fischeri and TU for E. coli, respectively, excluding the $\left[\mathrm{N}_{8881}\right]\left[\mathrm{C}_{18: 1}\right]$ FAIL and $0.81,0.15$ and 0.15 including it (Fig. 2). This can be explained considering that the properties of $\left[\mathrm{N}_{8881}\right]\left[\mathrm{C}_{18: 1}\right]$ can be slightly different from those of the other FAILs, since the former was synthesized from an unsaturated fatty acid (oleic acid) and the rest of them from saturated fatty acids. Besides, the purity of the oleic acid was lower than that of the other fatty acid precursors, which can negatively affect the toxicity of the $\left[\mathrm{N}_{8881}\right]\left[\mathrm{C}_{18: 1}\right] \mathrm{IL}$.
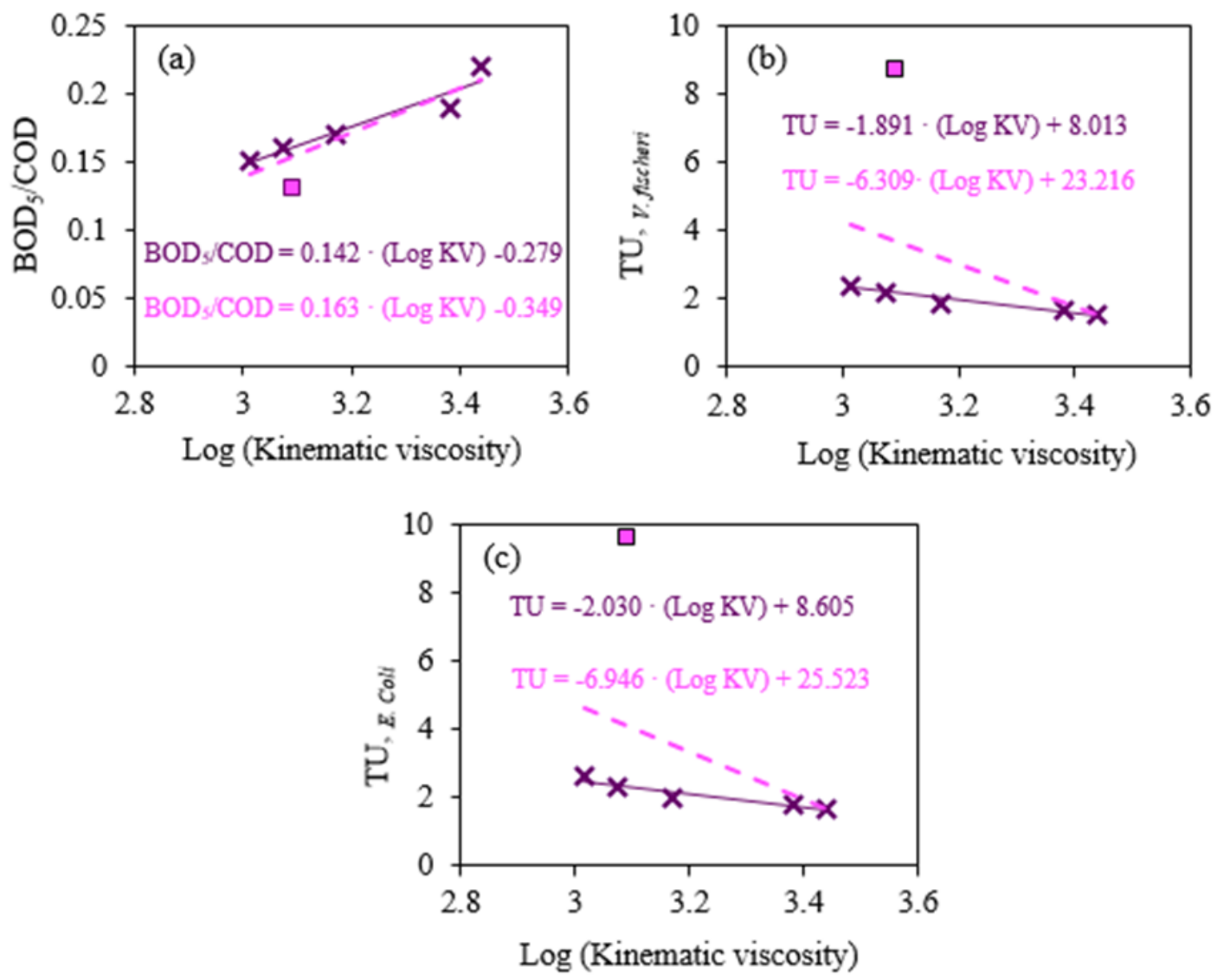

Fig. 2 Biodegradability index (a), TU for $V$. fischeri (b) and TU for $E$. coli (c) of the FAILs as a function of their kinematic viscosity $(\mathrm{KV})$. Saturated FAILs $(x)$ and the unsaturated FAIL $(\square)$. Fitting lines: solid, including only saturated FAILs; dashed line, including all FAILs. 
The relation between biodegradability and kinematic viscosity differ from that reported by Haus et al. [29], in which the biodegradability of commercial mineral paraffinic base oils decreased with the kinematic viscosity. Besides, the viscosity of molecular liquids tends to increase with the number of methylene groups and this behavior is also expected with ionic liquids. Using FAILs, Van der Waals interactions between the methylene units causes an increase in the interactive forces and, therefore, the viscosity of these ionic liquids should grow with increasing chain length [22]. However, the opposite trend was found in this research (Table 1), with viscosity rising when the chain length of the anion decreases. Although it is difficult to explain this change in the viscosity trend, at least another research study [38] found similar results working with a different family of ionic liquids (phosphonium phosphinate).

\subsubsection{Viscosity index}

Regarding the viscosity index, the values varied from 85 to 102 and it seems that the biodegradability index was a decreasing function of this parameter (Tables 1 and 2). The viscosity index indicates the dependence of viscosity on temperature. Thus, high values of viscosity index are desirable since the higher the value, the less the viscosity is influenced by temperature. Fig. 3a shows a quasi linear tendency $\left(r^{2}=0.76\right)$ between the biodegradability index and the logarithm of viscosity index, excluding the $\left[\mathrm{N}_{8881}\right]\left[\mathrm{C}_{6: 0}\right]$ FAIL. This can be explained considering that the viscosity index of this FAIL is higher than that expected due to the existence of some impurities because these FAILs are synthesized from natural fatty acids. 
Regarding TU, this parameter increased as the logarithm of viscosity index increased for both bacteria studies. It was found a linear relationship between them, the value of $\mathrm{r}^{2}$ being 0.94 for $V$. fischeri and 0.90 for $E$. coli excluding the $\left[\mathrm{N}_{8881}\right]\left[\mathrm{C}_{18: 1}\right]$ FAIL and 0.25 in both cases including it (Fig. $3 \mathrm{~b}$ and c). This can be explained taking into account the presence of impurities (arsenic, cadmium, mercury) in the unsaturated FAIL due to the lower purity of its precursor.
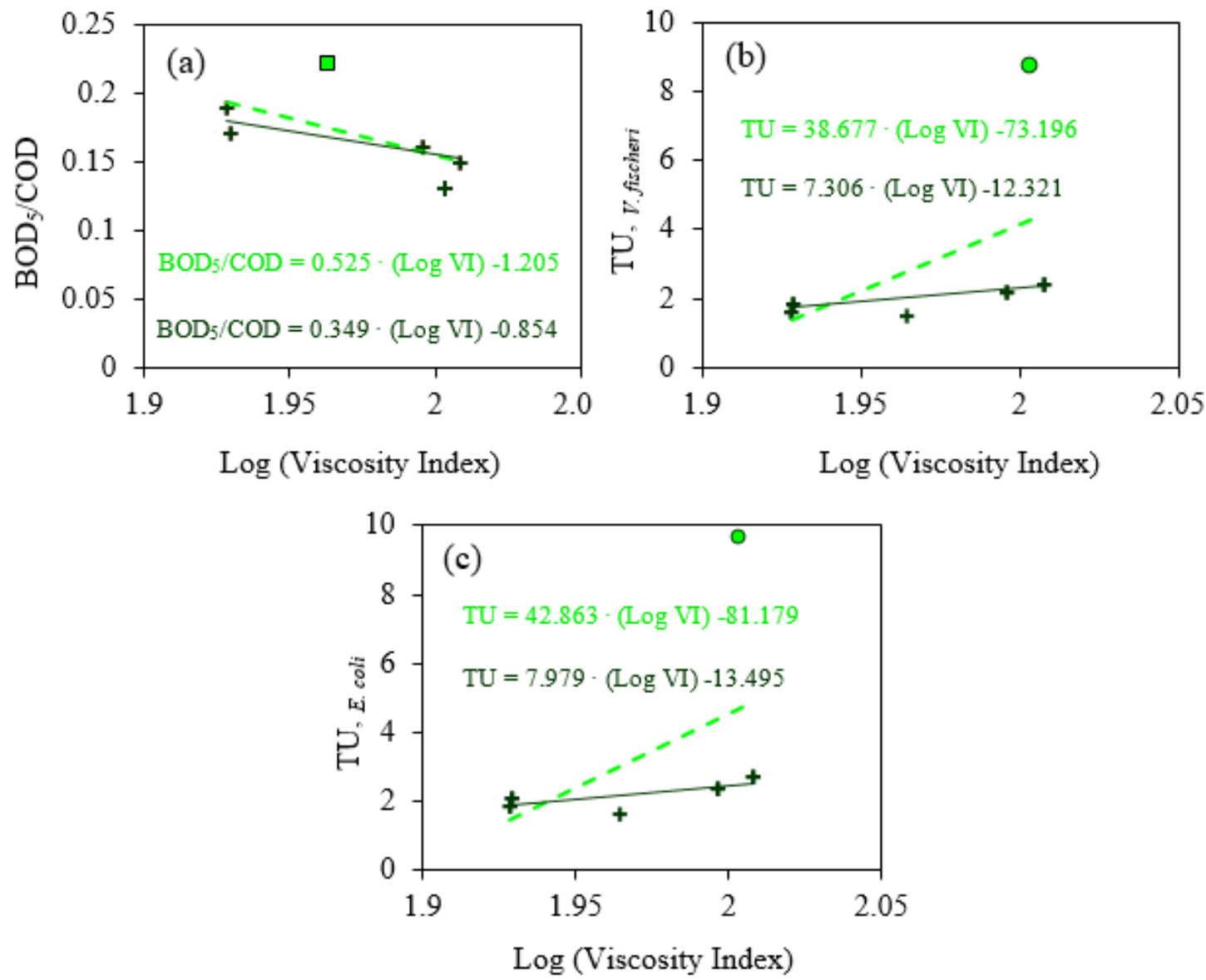

Fig. 3 Biodegradability index (a), TU for $V$. fischeri (b) and TU for E. coli (c) of the FAILs as a function of their viscosity index (VI): $\left[\mathrm{N}_{8881}\right]\left[\mathrm{C}_{6: 0}\right]$ FAIL $(\square),\left[\mathrm{N}_{8881}\right]\left[\mathrm{C}_{18: 1}\right]$ FAIL $(\odot)$ and the rest of the FAILs $(+)$.

Fitting lines: solid, excluding the $\left[\mathrm{N}_{8881}\right]\left[\mathrm{C}_{6: 0}\right]$ or $\left[\mathrm{N}_{8881}\right]\left[\mathrm{C}_{18: 1}\right] \mathrm{FAIL}$; and dashed line, including all FAILs. 


\subsubsection{Refractive index}

The refractive indices of the FAILs varied from 1.4620 to 1.4750 and decreased with the increase of the alkyl length of the anion in the case of the saturated FAILs (Table 1). It was observed that the biodegradability index of the FAILs increased with an increase in the refractive index, whereas the values of TU decreased. Besides, a good linear relationship $\left(r^{2}=0.96\right)$ between the biodegradability and refractive index was obtained for the saturated FAILs (Fig. 4a). On the contrary, such correlation became significantly worse when the unsaturated FAIL $\left(\left[\mathrm{N}_{8881}\right]\left[\mathrm{C}_{18: 1}\right]\right)$ was included $\left(\mathrm{r}^{2}=0.47\right)$. This can be due to the presence of the double bond in this compound, which makes it less prone to be degraded biologically. This is in contrast with the results reported by Haus et al. [28], who found out that the biodegradability of commercial mineral paraffinic base oils decreased with the refractive index. This can be due to the differences in the composition of the FAILs and the commercial base oils.
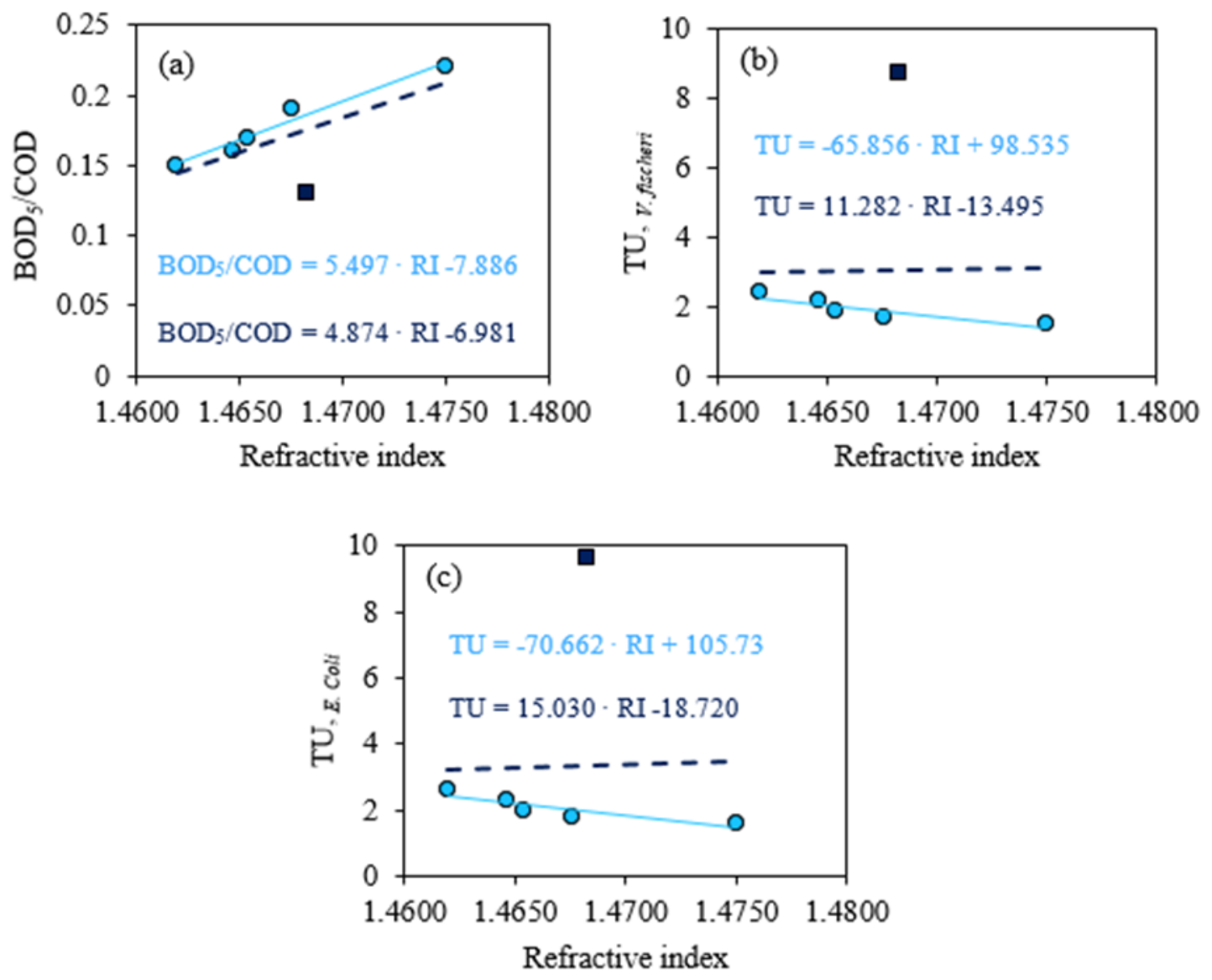

Fig. 4 Biodegradability index (a), TU for $V$. fischeri (b) and TU for E. coli (c) of the FAILs as a function of their refractive index (RI). Saturated FAILs $(\bullet)$ and the unsaturated FAIL ( $\square$ ). Fitting lines: solid, including only saturated FAILs; dashed line, including all FAILs. 
The relationship between TU units and refractive index proved to be quasi linear for the saturated FAILs on both $V$. fischeri and E.coli $\left(\mathrm{r}^{2}=0.79\right.$ and $\mathrm{r}^{2}=0.77$, respectively). Conversely, linearity was negligible ( $\mathrm{r}^{2}$ $=0.0005$ ) when considering the unsaturated FAIL (Figure $4 \mathrm{~b}$ and $\mathrm{c}$ ). These results can be explained based on: i) the existence of a double bond in its structure, which caused a significant increase in the toxicity and ii) the presence of impurities due to the lower purity of the fatty acid precursor. These results revealed that the biodegradability behavior can be successfully predicted by the refractive index. However, it only serves as an indicator of the toxicity inherent to the studied FAILs.

\subsubsection{Density}

Regarding the values of density, it seemed that the biodegradability index increased with a rise in density. However, the tendency in the case of TU was the contrary. A fairly linear function of biodegradability and density $\left(r^{2}=0.90\right)$ was also found with the saturated FAILs, being non-linear $\left(r^{2}=0.11\right)$ for the unsaturated one $\left(\left[\mathrm{N}_{8881}\right]\left[\mathrm{C}_{18: 1}\right]\right)($ Fig. 5a).
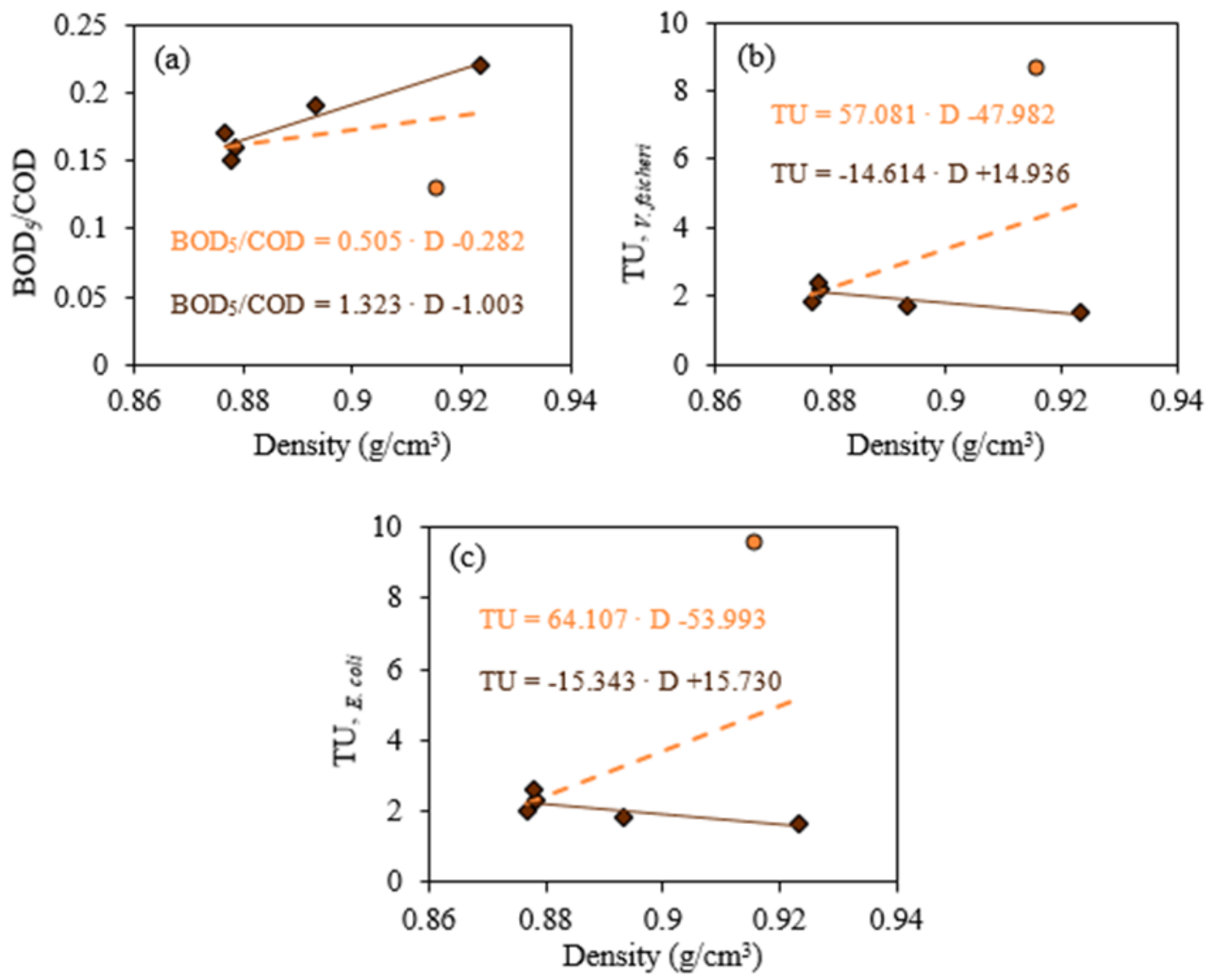

Fig. 5 Biodegradability index(a), TU for $V$. fischeri (b) and TU for E. coli (c) of the FAILs as a function of their density (D). Saturated FAILs $(\diamond)$ and the unsaturated FAIL ( $\odot$ ). Fitting lines: solid, including only saturated FAILs; dashed line, including all FAILs. 
For TU, the linearity with density for the saturated FAILs was poor on both bacteria, the $\mathrm{r} 2$ values being 0.62 for V. fischeri and 0.60 for E. coli (Fig. $5 \mathrm{~b}$ and c). In the same way as with biodegradability, the tendency was non-linear when the unsaturated FAIL was included $(\mathrm{r} 2=0.18)$. Hence, the presence of a double bond led to a weak linear tendency of the biodegradability index and the physical properties. On viewing the goodness of the linear fitting, density can be adequately used to estimate biodegradability but not toxicity.

\subsubsection{Water solubility}

Considering the water solubility of the FAILs, the biodegradability index increased as water solubility increased, whereas the TU values decreased. It should be noted that a decrease in the alkyl chain length of the anion caused a rise in the hydrophilicity. These experimental results are in agreement with the values found in the literature, especially for the imidazolium-based ionic liquids in which the longer the alkyl chain is, the smaller is the solubility of ILs in water $[39,40]$. This is the responsible for both the increase in water solubility and biodegradability and reduction in toxicity. It was found a linear relationship between the biodegradability index and water solubility, the $\mathrm{r}^{2}$ value being 0.95 excluding the $\left[\mathrm{N}_{8881}\right]\left[\mathrm{C}_{18: 1}\right]$ FAIL and 0.89 including it (Fig. 6a). For the TU units, the relationship was quasi linear $\left(\mathrm{r}^{2}=0.81\right)$ on both bacteria for the saturated FAILs, this being non-linear $\left(\mathrm{r}^{2}=0.22\right)$ when the $\left[\mathrm{N}_{8881}\right]\left[\mathrm{C}_{18: 1}\right]$ FAIL was considered (Fig. $6 \mathrm{~b}$ and $\mathrm{c})$. Again, the existence of a double bond modifies the characteristics of this FAIL, which worsens or even removes the linear correlation trend.
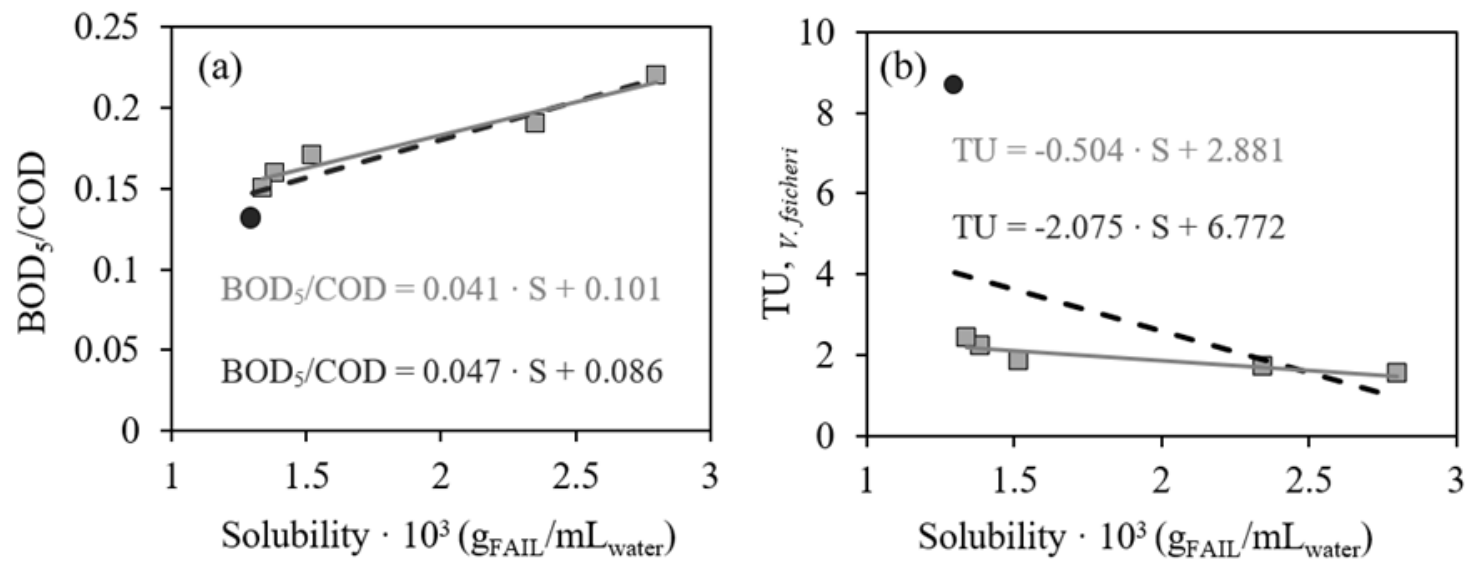


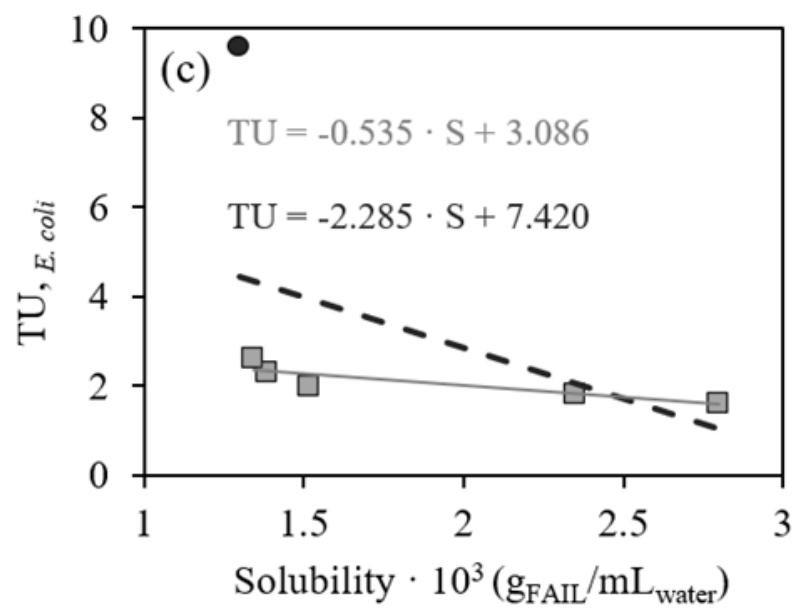

Fig. 6 Biodegradability index (a), TU for $V$. fischeri (b) and TU for E. coli (c) of the FAILs as a function of their solubility (S). Saturated FAILs $(\square)$ and the unsaturated FAIL $(\bullet)$. Fitting lines: solid, including only saturated FAILs; dashed line, including all FAILs.

\section{Conclusions}

Several physical properties were correlated with the environmental performance (biodegradability and bacteria toxicity) on a series of ionic liquids synthesized from natural fatty acids as anion precursors. From the results obtained, the following conclusions can be drawn:

- A good linear relationship between the biodegradability index of the saturated FAILs $\left(\left[\mathrm{N}_{8881}\right]\left[\mathrm{C}_{6: 0}\right],\left[\mathrm{N}_{8881}\right]\left[\mathrm{C}_{8: 0}\right],\left[\mathrm{N}_{8881}\right]\left[\mathrm{C}_{12: 0}\right],\left[\mathrm{N}_{8881}\right]\left[\mathrm{C}_{16: 0}\right]\right.$ and $\left.\left[\mathrm{N}_{8881}\right]\left[\mathrm{C}_{18: 0}\right]\right)$ and the following physical properties were obtained: i) the logarithm of kinematic viscosity, ii) refraction index and iii) water solubility. It was also found that the biodegradability index of the saturated FAILs increased with an increase in the kinematic viscosity, refractive index and water solubility.

- $\quad$ Regarding TU, for both Vibrio fischeri and Escherichia Coli, the best linear relationships $\left(\mathrm{r}^{2}>\right.$ 0.90) for the saturated FAILs were achieved with the logarithm of kinematic viscosity and viscosity index. Considering that kinematic viscosity is an important parameter for a lubricant, this physical property is promising in evaluating both biodegradability and toxicity.

- Other physical properties, including refractive index, density and water solubility can only serve as indicators to estimate the toxicity.

- The presence of a double bond in the structure of the $\left[\mathrm{N}_{8881}\right]\left[\mathrm{C}_{18: 1}\right]$ FAIL modifies its properties, which caused a significant worsening in the linear dependence between environmental and physical properties. 


\section{Acknowledgements}

The authors acknowledge the Spanish Ministry of Economy and Competitiveness and the Foundation for the Promotion of Applied Scientific Research and Technology in Asturias (FICYT) for granting this research under the framework of the projects FAILs_LUBEs (MINECO-17-DPI2016-79690-R) and LuSuTec (FC-GRUPIN-IDI/2018/000131), respectively.

\section{References}

[1] Dong R, Wen P, Zhang S, Zhang C, Sun W, Fan M, et al. The synthesis and tribological properties of dicarboxylic acid ionic liquids. Tribol Int 2017;114:132-40. doi:10.1016/j.triboint.2017.04.012.

[2] Federici Canova F, Matsubara H, Mizukami M, Kurihara K, Shluger AL. Shear dynamics of nanoconfined ionic liquids. Phys Chem Chem Phys 2014;16(18):8247-56. doi:10.1039/C4CP00005F.

[3] Tariq M, Freire MG, Saramago B, Coutinho JAP, Lopes JNC, Rebelo LPN. Surface tension of ionic liquids and ionic liquid solutions. Chem Soc Rev doi:2012;41(2):829-68. 10.1039/C1CS15146K.

[4] Petkovic M, Seddon KR, Rebelo LPN, Silva Pereira C. Ionic liquids: a pathway to environmental acceptability. Chem Soc Rev 2011;40(3):1383-403. doi: 10.1039/C004968A.

[5] Amaral L, Cardoso DSP, Šljukić B, Santos DMF, Sequeira CAC. Electrochemistry of hydrogen evolution in ionic liquids aqueous mixtures. Mater Res Bull 2019;112:407-12. doi:10.1016/j.materresbull.2018.04.041.

[6] Vekariya RL. A review of ionic liquids: Applications towards catalytic organic transformations. J Mol Liq 2017;227:44-60. doi:10.1016/j.molliq.2016.11.123.

[7] Steinrück H-P, Libuda J, Wasserscheid P, Cremer T, Kolbeck C, Laurin M, et al. Surface Science and Model Catalysis with Ionic Liquid-Modified Materials. Adv Mater 2011;23(22-23):257187. doi:10.1002/adma.201100211.

[8] Olivier-Bourbigou H, Magna L, Morvan D. Ionic liquids and catalysis: Recent progress from knowledge to applications. Appl Catal A-Gen 2010;373(1):1-56. doi:10.1016/j.apcata.2009.10.008. 
[9] Quan X, Zhang S, Hu M, Gao X, Jiang D, Sun J. Tribological properties of WS2/MoS2-Ag composite films lubricated with ionic liquids under vacuum conditions. Tribol Int 2017;115:389-96. doi: 10.1016/j.triboint.2017.06.002.

[10] Hernández Battez A, Bartolomé M, Blanco D, Viesca JL, Fernández-González A, González R. Phosphonium cation-based ionic liquids as neat lubricants: Physicochemical and tribological performance. Tribol Int 2016;95:118-31. doi:10.1016/j.triboint.2015.11.015.

[11] Otero I, López ER, Reichelt M, Villanueva M, Salgado J, Fernández J. Ionic Liquids Based on Phosphonium Cations As Neat Lubricants or Lubricant Additives for a Steel/Steel Contact. ACS Appl Mater Inter. 2014;6(15):13115-28. doi:10.1021/am502980m.

[12] García A, González R, Hernández Battez A, Viesca JL, Monge R, Fernández-González A, et al. Ionic liquids as a neat lubricant applied to steel-steel contacts. Tribol Int 2014;72:42-50. doi:10.1016/j.triboint.2013.12.007.

[13] Somers AE, Khemchandani B, Howlett PC, Sun J, MacFarlane DR, Forsyth M. Ionic Liquids as Antiwear Additives in Base Oils: Influence of Structure on Miscibility and Antiwear Performance for Steel on Aluminum. ACS Appl Mater Inter 2013;5(22):11544-53. doi:10.1021/am4037614.

[14] Somers AE, Biddulph SM, Howlett PC, Sun J, MacFarlane DR, Forsyth M. A comparison of phosphorus and fluorine containing IL lubricants for steel on aluminium. Phys Chem Chem Phys 2012;14(22):8224-31. doi:10.1039/C2CP40736A.

[15] Battez AH, González R, Viesca JL, Blanco D, Asedegbega E, Osorio A. Tribological behaviour of two imidazolium ionic liquids as lubricant additives for steel/steel contacts. Wear 2009;266(11):1224-8. doi:10.1016/j.wear.2009.03.043.

[16] Minami I. Ionic Liquids in Tribology. Molecules. 2009;14(6):2286.doi:10.3390/molecules 14062286.

[17] Zhou Y, Leonard DN, Guo W, Qu J. Understanding Tribofilm Formation Mechanisms in Ionic Liquid Lubrication. Sci Rep-UK. 2017;7(1):8426. doi:10.1038/s41598-017-09029-Z.

[18] Hernández Battez A, Blanco D, Fernández-González A, Mallada MT, González R, Viesca JL. Friction, wear and tribofilm formation with a [NTf2] anion-based ionic liquid as neat lubricant. Tribol Int. 2016;103:73-86. doi:10.1016/j.triboint.2016.06.038. 
[19] Cai M, Liang Y, Yao M, Xia Y, Zhou F, Liu W. Imidazolium Ionic Liquids As Antiwear and Antioxidant Additive in Poly(ethylene glycol) for Steel/Steel Contacts. ACS Appl Mater Inter 2010;2(3):870-6. doi:10.1021/am900847j.

[20] Yakubov GE, Zhong L, Li M, Boehm MW, Xie F, Beattie DA, et al. Lubrication of starch in ionic liquid-water mixtures: Soluble carbohydrate polymers form a boundary film on hydrophobic surfaces. Carbohyd Polym 2015;133:507-16. di:10.1016/j.carbpol.2015.06.087.

[21] Madanhire I, Mbohwa C. Mitigating Environmental Impact of Petroleum Lubricants: Springer International Publishing; 2016.

[22] Gusain R, Khatri OP. Fatty acid ionic liquids as environmentally friendly lubricants for low friction and wear. RSC Adv 2016;6(5):3462-9. doi:10.1039/C5RA25001C.

[23] Hulsbosch J, De Vos DE, Binnemans K, Ameloot R. Biobased Ionic Liquids: Solvents for a Green Processing Industry? ACS Sustain Chem Eng 2016;4(6):2917-31. doi:10.1021/acssuschemeng.6b00553.

[24] Rocha MAA, van den Bruinhorst A, Schröer W, Rathke B, Kroon MC. Physicochemical properties of fatty acid based ionic liquids. J Chem Thermodyn 2016;100:156-64. doi:10.1016/j.jct.2016.04.021.

[25] Li Z, Liu X, Pei Y, Wang J, He M. Design of environmentally friendly ionic liquid aqueous twophase systems for the efficient and high activity extraction of proteins. Green Chem 2012;14(10):2941-50. doi:10.1039/C2GC35890E.

[26] Pretti C, Chiappe C, Baldetti I, Brunini S, Monni G, Intorre L. Acute toxicity of ionic liquids for three freshwater organisms: Pseudokirchneriella subcapitata, Daphnia magna and Danio rerio. Ecotox Environ Safe. 2009;72(4):1170-6. doi:10.1016/j.ecoenv.2008.09.010.

[27] Oliveira MVS, Vidal BT, Melo CM, de Miranda RdCM, Soares CMF, Coutinho JAP, et al. (Eco)toxicity and biodegradability of protic ionic liquids. Chemosphere. 2016;147:460-6. doi:10.1016/j.chemosphere.2015.11.016.

[28] Haus F, German J, Junter G-A. Primary biodegradability of mineral base oils in relation to their chemical and physical characteristics. Chemosphere. 2001;45(6):983-90. doi:10.1016/S0045$6535(01) 00027-3$ 
[29] Haus F, Junter G-A, German J. Viscosity properties of mineral paraffinic base oils as a key factor in their primary biodegradability. Biodegradation. 2000;11(6):365. doi:10.1023/a:1011672016757.

[30] Willing A. Oleochemical esters - environmentally compatible raw materials for oils and lubricants from renewable resources. Lipid / Fett. 1999;101(6):192-8. doi:10.1002/(sici)15214133(199906)101:6<192::aid-lipi192>3.0.co;2-w.

[31] Battez AH, Rivera N, Blanco D, Oulego P, Viesca JL, González R. Physicochemical, traction and tribofilm formation properties of three octanoate-, laurate- and palmitate-anion based ionic liquids. J Mol Liq 2019;284:639-46. doi:10.1016/j.molliq.2019.04.050.

[32] Blanco D, Rivera N, Oulego P, Díaz M, González R, Battez, AH Novel fatty acid anion-based ionic liquids: Contact angle, surface tension, polarity fraction and spreading parameter. J Mol Liq 2019;288:110995. doi.org/10.1016/j.molliq.2019.110995.

[33] Oulego P, Blanco D, Ramos D, Viesca JL, Díaz M, Hernández Battez A. Environmental properties of phosphonium, imidazolium and ammonium cation-based ionic liquids as potential lubricant additives. J Mol Liq 2018;272:937-47. doi:10.1016/j.molliq.2018.10.106.

[34] ISO 11348-3, Water Quality - Determination of the Inhibitory Effect of Water Samples on the Light Emission of Vibrio fischeri (Luminescent Bacteria Test), International Standardization Organization, Geneva, 2007.

[35] Thompson KC, Wadhia K, Loibner AP. Environmental Toxicity testing, 1st ed., Blackwell publishing, CRC Press, UK, 2005.

[36] Chang SC, Wang YF, You SJ, Kuo YM, Tsai CH, Wang LC, Hsu PY. Toxicity evaluation of fly ash by Microtox®. Aerosol Air Qual Res 2013;13:1002-8. doi:10.4209/aaqr.2012.10.0267.

[37] Metcalf and Eddy. Wastewater Engineering: Treatment, Disposal and Reuse, 4th. Ed. McGrawHill Inc., New York, USA, 2003.

[38] Liu X, Afzal W, Prausnitz JM. Unusual trend of viscosities and densities for four ionic liquids containing a tetraalkyl phosphonium cation and the anion bis(2,4,4- trimethylpentyl) phosphinate. J Chem Therm 2014;70;122-126. doi.org/10.1016/j.jct.2013.09.037.

[39] Freire MG, Santos LMNBF, Fernandes AM, Coutinho JAP, Marrucho IM. An overview of the mutual solubilities of water-imidazolium-based ionic liquids systems. Fluid Phase Equilibria 2007; 261(1-2): 449-454. doi.org/10.1016/j.fluid.2007.07.033. 
[40] Kakiuchi T. Mutual Solubility of Hydrophobic Ionic Liquids and Water in Liquid-Liquid Twophase Systems for Analytical Chemistry. Analytical Sciences 2008;24(10):1221-1230. doi.org/10.2116/analsci.24.1221. 